\title{
CHROMOSOMAL LOCATIONS OF HIGHLY REPEATED DNA SEQUENCES IN WHEAT
}

\author{
W. L. GERLACH and W. J. PEACOCK \\ Division of Plant Industry, Commonwealth Scientific and Industrial Research Organisation, P.O. Box \\ 1600, Canberra City, ACT 2601, Australia
}

Received 17.ix.79

\begin{abstract}
SUMMARY
$\mathrm{C}_{0} \mathrm{t} 10^{-2}$ DNA was isolated from hexaploid wheat Triticum aestivum cv. Chinese Spring by hydroxyapatite chromatography $\left(70^{\circ} \mathrm{C}\right.$ in $0.12 \mathrm{~m}$ phosphate buffer). The higher $T_{m}$ of the $\mathrm{C}_{0} \mathrm{t} 10^{-2}$ DNA compared with total wheat DNA suggested that it was relatively GC rich and contained well matched hybrids. In situ hybridisation using wheat species of different ploidy levels located major sites of the $\mathrm{C}_{0} \mathrm{t} 10^{-2}$ DNA on the $\mathrm{B}$ genome chromosomes. More than one particular highly repeated sequence is located in these sites. Other chromosomal locations could be visualised by heating in situ hybridisation reactions before renaturation. This was attributed to the availability for hybridisation both of chromosomal sequences additional to those normally available after acid denaturation of cytological preparations and to single stranded cRNA molecules which were otherwise present as double stranded structures.
\end{abstract}

\section{INTRODUCTION}

HighLY repeated DNA sequences, sometimes detected as rapidly reassociating DNA (Britten and Kohne, 1968), are a characteristic component of eukaryotic genomes. Rapidly renaturing fractions of hexaploid wheat DNA have been isolated (Mitra and Bhatia, 1973; Smith and Flavell, 1974, 1975; Dover, 1975; Flavell and Smith, 1976; Ranjekar et al., 1976), up to 10 per cent of the genome being recovered as duplexes by hydroxyapatite chromatography after reassociation to $\mathrm{C}_{0} \mathrm{t}$ values between $8 \times 10^{-3}$ and $2 \times 10^{-2} \mathrm{~mol} \mathrm{sec}^{-1}$ in $0.12 \mathrm{M}$ phosphate buffer at $60^{\circ} \mathrm{C}$. This DNA had thermal stabilities $8-10^{\circ} \mathrm{C}$ lower than that of native, total wheat DNA indicating that mismatched hybrids had been isolated (Dover, 1975; Smith and Flavell, 1975; Ranjekar et al., 1976), and Ranjekar et al. (1976) found that the buoyant density profile was broad, with a mean density of 1.708 $\mathrm{gm} / \mathrm{cm}^{3}$ compared with the density of $1.702 \mathrm{gm} / \mathrm{cm}^{3}$ of the total, native wheat DNA. The mismatching in the renatured molecules may be the result of sequence divergence during the evolution of the families of repeated DNAs (Flavell et al., 1977).

The work described in this paper was undertaken to characterise the chromosomal locations of the rapidly renatured DNA $\mathrm{C}_{0} \mathrm{t} 10^{-2}$ fractions which were isolated by hydroxyapatite chromatography under conditions which ensured that only well matched hybrids were formed. In situ cytological hybridisation located this DNA at sites on all chromosomes with distinct, major sites being present on the B genome chromosomes. 


\section{Materials and methods}

\section{(i) Isolation of highly repeated $D \mathcal{N A}$}

DNA was isolated from 3-day-old seedlings of hexaploid wheat Triticum aestivum cv. Chinese Spring grown at $27^{\circ} \mathrm{C}$ from surface sterilised seeds. Approximately 1000 seedlings were frozen in liquid nitrogen and homogenised to powder in a Waring Blender at high speed for $4 \mathrm{~min}$. Following the addition of $250 \mathrm{ml}$ buffer $(0.15 \mathrm{~m} \mathrm{NaCl}, 0.1 \mathrm{~m} \mathrm{EDTA}, p \mathrm{H}=8.0)$, the mixture was homogenised for a further $2 \mathrm{~min}$. at high speed; $2 \mathrm{~g}$ sodium lauryl sulphate was added and the suspension heated to $60^{\circ} \mathrm{C}$ for $20 \mathrm{~min}$. before addition of $100 \mathrm{mg}$ Pronase (Sigma) and further incubation for 1 hour at $45^{\circ} \mathrm{C}$. The suspension was made $0.55 \mathrm{~m}$ with $\mathrm{NaCl}$, centrifuged to remove particulate material and then extracted with an equal volume of phenol. The phenol was washed twice with water and nucleic acid was precipitated by addition of 2 volumes of ethanol $\left(-20^{\circ} \mathrm{C}\right)$ to the pooled aqueous fractions. RNase A (Sigma, $10 \mu \mathrm{g} / \mathrm{ml}, 37^{\circ} \mathrm{C}, 30 \mathrm{~min}$.) treatment followed resuspension of the DNA pellet in $2 \times \mathrm{SSC}$ ( $\mathrm{SSC}$ is $0 \cdot 15 \mathrm{~m} \mathrm{NaCl}, 0 \cdot 015 \mathrm{~m}$ sodium citrate). The DNA was again precipitated with two volumes of ethanol and purified by centrifugation in a CsGl buoyant density gradient. DNA was stored in TE (10 mm Tris- $\mathrm{HCl}, 1 \mathrm{~mm} \mathrm{EDTA,} p \mathrm{H}=8.4$ ) at $4^{\circ} \mathrm{C}$.

For isolation of a rapidly renaturing DNA fraction the total DNA was first sheared by three passages through an Aminco French Pressure Cell (16,000 p.s.i.). Average single stranded DNA fragment length, calculated from the sedimentation velocity in $0.9 \mathrm{M} \mathrm{NaCl}, 0.1 \mathrm{~m} \mathrm{NaOH}$ (Studier, 1965), was 700 bases. In two separate experiments the sheared DNA (15.8 and $15.2 \mu \mathrm{g} / \mathrm{ml}$ respectively) in $0.12 \mathrm{~m} \mathrm{~PB}$ (Sorensen's phosphate buffer, $p \mathrm{H}=$ $6 \cdot 8$ ) was denatured by heating to $100^{\circ} \mathrm{C}$ and aliquots incubated at $70^{\circ} \mathrm{C}$ to allow renaturation. The rapidly renaturing fraction was isolated by hydroxyapatite chromatography using a jacketed column maintained at $70^{\circ} \mathrm{C}$. Flow rate was adjusted so that the average $\mathrm{C}_{0} \mathrm{t}$ value of reassociated DNA aliquots applied to the column was $\mathrm{C}_{0} \mathrm{t} 10^{-2} \mathrm{~mol} \mathrm{sec} .1^{-1}$ (range = $\mathrm{C}_{0}$ t $0.5 \times 10^{-2}$ to $1.5 \times 10^{-2}$ ). DNA bound to the column was eluted with $0.5 \mathrm{~m} \mathrm{~PB}$ at $70^{\circ} \mathrm{C}$.

\section{(ii) Thermal dissociation profiles}

DNA samples were co-dialysed with Escherichia coli DNA (Sigma) against TE. The $E$. coli DNA was included in each experiment as an internal control; the melting temperature of the sample was adjusted relative to a standard melting temperature for $E$. coli DNA of $65.8^{\circ} \mathrm{C}$ in TE. Hyperchromicity was expressed as the percent increase in optical density $(260 \mathrm{~nm})$ compared with the initial optical density of the sample. Profiles were obtained with a Gilford recording spectrophotometer, with temperature programmed to increase at either 45 or $60^{\circ} \mathrm{C} /$ hour.

\section{(iii) Preparation of $c R \mathcal{N A}$}

${ }^{3} \mathrm{H}-\mathrm{cRNA}$ (RNA complementary to a DNA template) was prepared using $E$. coli RNA polymerase. The reaction mixture $(0.1 \mathrm{ml})$ contained $4 \mu \mathrm{g}$ DNA template, $6-7 \times 10^{-4} \mu$ moles of ${ }^{3} \mathrm{H}-\mathrm{GTP}$, CTP, UTP, $10^{-4}$ moles ATP and E. coli RNA polymerase (prepared according to Burgess, 1969) 
in $0.04 \mathrm{~m}$ Tris- $\mathrm{HCl} p \mathrm{H}=7.9,0.01 \mathrm{~m}^{\mathrm{MgCl}_{2}}, 0.16 \mathrm{M} \mathrm{KGl}$ and $2 \times 10^{-4} \mathrm{M}$ dithiothreitol at $37^{\circ} \mathrm{C}$. After $2-3$ hours the template was removed by DNase treatment (Worthington DPFF, $100 \mu \mathrm{g} / \mathrm{ml}, 30 \mathrm{~min}$.) and the cRNA isolated by phenol extraction, G-75 Sephadex chromatography and ethanol precipitation. cRNA preparations were stored in $6 \times \mathrm{SSC}$ at $-20^{\circ} \mathrm{C}$.

\section{(iv) In situ hybridisation}

To accumulate root tip metaphases, 3-day-old seedlings grown at $27^{\circ} \mathrm{C}$ were treated with 0.25 per cent colchicine for 3 hours prior to fixation in $1: 3$ acetic ethanol. Root tip squashes were prepared in 45 per cent acetic acid, dehydrated in absolute alcohol and air dried before chromosomal DNA was denatured in $0.2 \mathrm{~N} \mathrm{HCl}\left(37^{\circ} \mathrm{C}, 30 \mathrm{~min}\right.$. $)$. Slides were then dehydrated through an alcohol series and air dried. $5 \mu \mathrm{l}$ of ${ }^{3} \mathrm{H}$-cRNA in $3 \times \mathrm{SSC}$, 50 per cent formamide $\left(10^{4}-10^{5} \mathrm{cpm} / \mu \mathrm{l}\right)$ was placed on each slide, covered with an $18 \mathrm{~mm}^{2}$ cover slip, sealed with rubber gum. Slides were then incubated for 3 hours at $40^{\circ} \mathrm{C}$ to effect hybridisation. Cover slips were removed and slides were washed twice in $3 \times \mathrm{SSC}, 50$ per cent formamide $\left(10 \mathrm{~min}\right.$. each wash, $\left.40^{\circ} \mathrm{G}\right)$, twice in $2 \times \mathrm{SSC}\left(10 \mathrm{~min}\right.$. each, $\left.40^{\circ} \mathrm{G}\right)$ before RNase treatment $(10 \mu \mathrm{g} / \mathrm{ml}$ Sigma pancreatic RNase, 1.25 units $/ \mathrm{ml}$ Calbiochem $\mathrm{T}_{1}$ RNase in $2 \times \mathrm{SSC}, 30 \mathrm{~min}$. at $37^{\circ} \mathrm{G}$ ). Following six further washes in $2 \times$ SSC the slides were ethanol dehydrated, air dried and coated with Ilford K2 emulsion (50 per cent dilution). Exposures were left for 1-3 weeks. Developed slides were stained with 1 per cent Gurr's Giemsa in $0 \cdot 2$ м $\mathrm{PB}, p \mathbf{H}=6 \cdot 8$.

In "pre-heated" hybridisation, slides complete with sealed reaction mixture, were placed at $75^{\circ} \mathrm{C}$ for 30 sec. prior to incubation at $40^{\circ} \mathrm{C}$.

Species used in in situ hybridisation experiments were: hexaploid wheat, Triticum aestivum cv. Chinese Spring, $2 n=42$; tetraploid wheat, T. dicoccoides W1043, $2 n=28$; diploid wheat, $T$. monococcum W292, $2 n=14$; and Aegilops squarrosa G46, $2 n=14$. Hexaploid wheat was donated by $\mathrm{Dr}$ $\mathrm{K}$. Shepherd, University of Adelaide, and the other species were a gift from Mr R. Dunstone, CSIRO, Division of Plant Industry.

\section{(v) Filter hybridisation}

Sartorius Membrane Filters (47 mm diameter) were washed for $30 \mathrm{~min}$. in $4 \times \mathrm{SSC}$, placed on a Millipore filtration apparatus and washed with $40 \mathrm{ml}$ $4 \times \mathrm{SSC}$. $120 \mu \mathrm{g}$ total wheat DNA (estimated from $\mathrm{OD}_{260}$ ) was denatured in $40 \mathrm{ml} 4 \times \mathrm{SSC}$ and $5 \mathrm{ml} 1 \mathrm{~N} \mathrm{KOH}$ at room temperature and cooled in ice after $5 \mathrm{~min}$. The DNA was neutralised by adding $5 \mathrm{ml} 1 \mathrm{~N} \mathrm{HCl}$ and loaded onto the filters by vacuum filtration. The effective area of the filter loaded with DNA was $35 \mathrm{~mm}$ diameter. Small filters $(7.75 \mathrm{~mm}$ diameter) were cut from the large filter and dried overnight in a vacuum oven at $60^{\circ} \mathrm{C}$. Blank filters were prepared by omitting the DNA in the loading solution.

For hybridisation, the filters were first washed for $10 \mathrm{~min}$. in $3 \times \mathrm{SSC}$, 50 per cent formamide at $40^{\circ} \mathrm{C}$. One DNA-filter and one blank filter was added to each of a series of vials containing $0.5 \mathrm{mI} 3 \times \mathrm{SSC}, 50$ per cent formamide, $2 \mu \mathrm{l}{ }^{3} \mathrm{H}$-cRNA $\left(2.9 \times 10^{5} \mathrm{cpm} / \mu \mathrm{l}\right)$ and $5 \mu \mathrm{l}$ unlabelled yeast RNA. If preheating of the hybridisation mixture was required the vials were heated to $70^{\circ} \mathrm{C}$ for $3 \mathrm{~min}$. at this stage. The hybridisation was carried 
out with gentle shaking at $40^{\circ} \mathrm{C}$. Both blank and DNA-filters were removed at given times, rinsed in $3 \times \mathrm{SSC}, 50$ per cent formamide and placed in fresh $3 \times \mathrm{SSC}, 50$ per cent formamide until the end of the experiment. At the end of the experiment they were washed en masse with $3 \times \mathrm{SSC}(3 \times 50 \mathrm{ml}$ washes, $5 \mathrm{~min}$. each) and treated with RNase (20 $\mu \mathrm{g}$ Sigma pancreatic RNase A, 50 units Calbiochem $\mathrm{T}_{1}$ RNase in $2.5 \mathrm{ml} 3 \times \mathrm{SSG}$ ). Following RNase treatment the filters were washed with $3 \times \mathrm{SSC}$ for $5 \mathrm{~min}$., dried at $60^{\circ} \mathrm{C}$ and counted. Radioactive label bound to each filter containing DNA was corrected for background as measured by the blank filter (this was always $60-75 \mathrm{cpm}$ ).

\section{Results AND Discussion}

\section{(i) Rapidly renaturing $D \mathcal{N} A$}

$\mathrm{C}_{0} \mathrm{t} 10^{-2} \mathrm{DNA}$ accounted for $7 \cdot 2$ per cent and 13.0 per cent of the DNA recovered from the hydroxyapatite columns in the two experiments. The total proportion of applied DNA recovered from the hydroxyapatite was 90 per cent and 83 per cent respectively. The differences between the two isolations may be due to different flow rates and bed volumes of the columns used (Britten et al., 1974). Thermal dissociation profiles for total wheat DNA and the $\mathrm{C}_{0} \mathrm{t} 10^{-2}$ isolates in TE (fig. 1) show total native wheat DNA with a $T_{m}$ of $63.0^{\circ} \mathrm{C}$, significantly lower than the $T_{m}$ 's of the $\mathrm{C}_{0} \mathrm{t} 10^{-2}$ fractions $\left(70.7^{\circ} \mathrm{C}\right.$ and $69.1^{\circ} \mathrm{C}$ respectively). The lower $T_{m}$ of the second

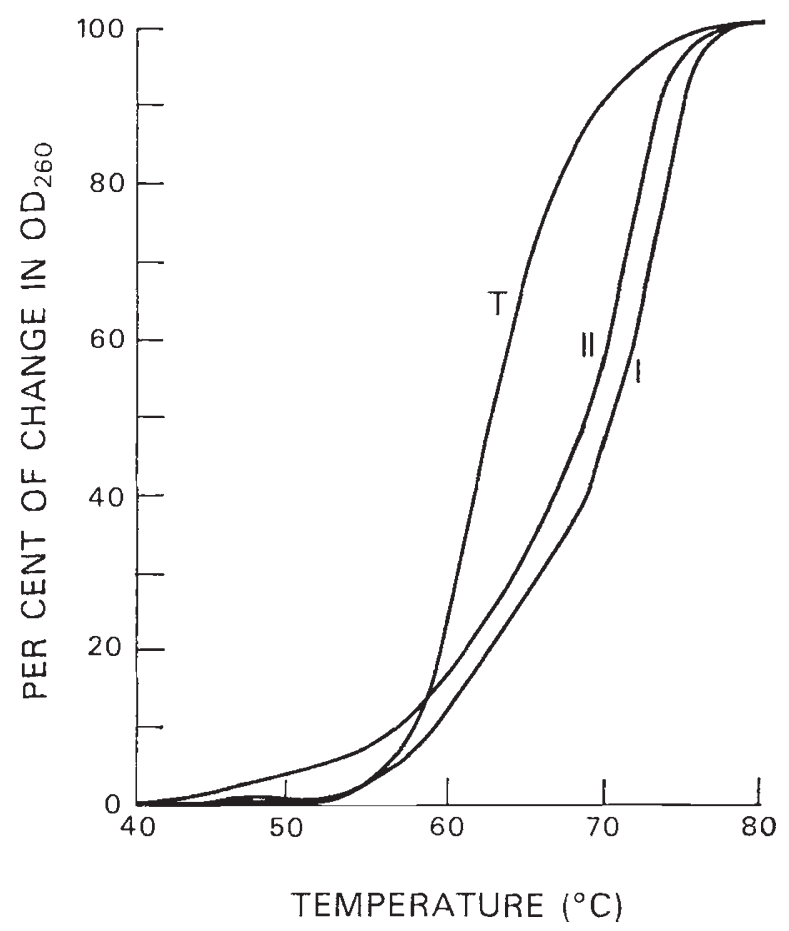

FIG. 1.-Thermal denaturation profiles of total native wheat DNA (T) and two different $\mathrm{C}_{0} \mathrm{t} 10^{-2}$ fractions (I and II) in $10 \mathrm{~mm}$ Tris, $1 \mathrm{~mm}$ EDTA, $p \mathrm{H}=8.4$. 


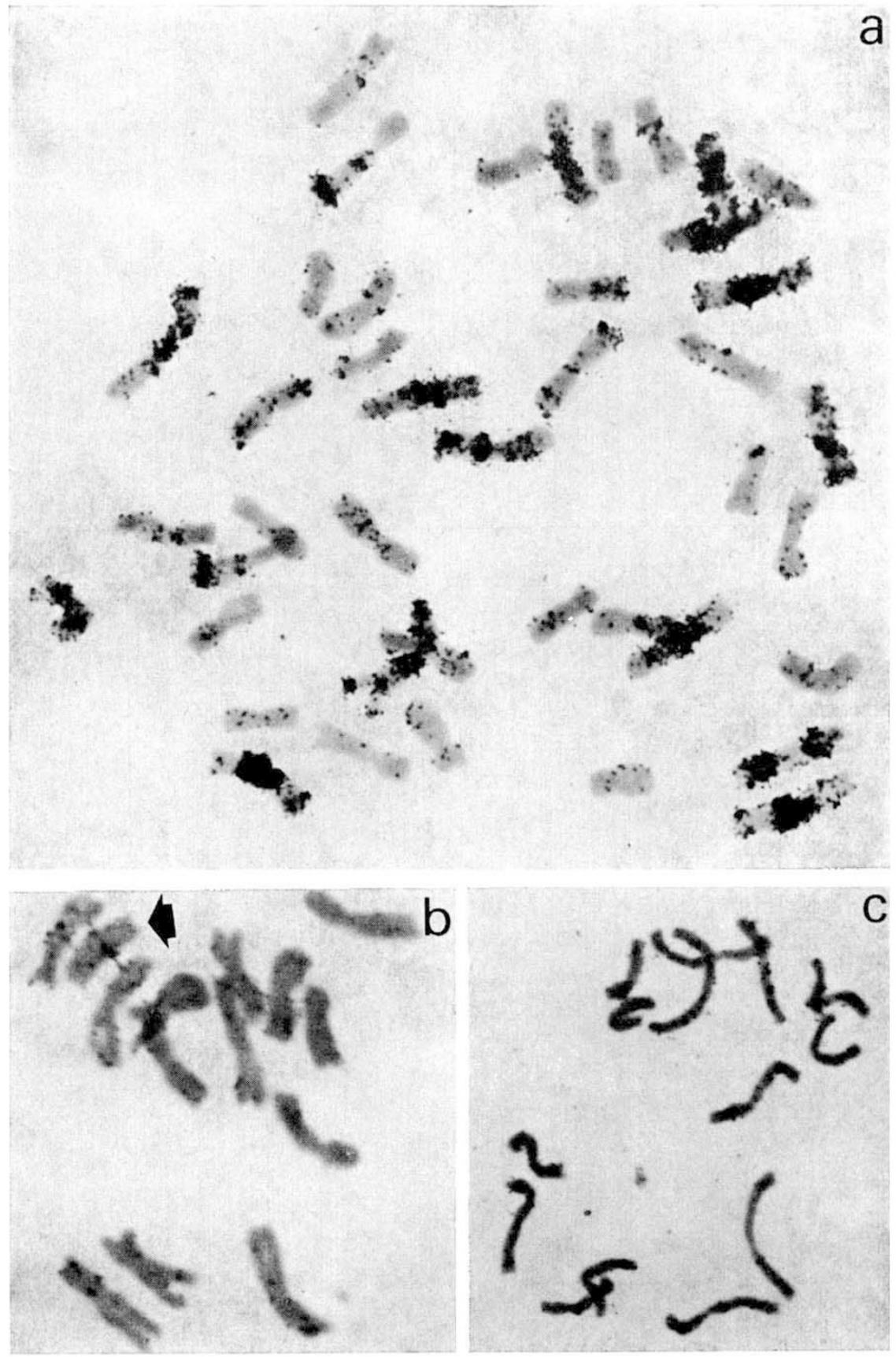

FIg. 2.-Autoradiographs after in situ hybridisation at $40^{\circ} \mathrm{C}$ with ${ }^{3} \mathrm{H}-\mathrm{cRNA}$ to $\mathrm{C}_{0} \mathrm{t} 10^{-2}$ DNA. Root tip metaphase cells of Triticum aestivum (a), T. monococcum (b) and Aegilops squarrosa (c). One pair of $T$. monococcum chromosomes, arrowed in $2 \mathrm{~b}$, show a major centromeric hybridisation site relative to the other locations of the cRNA. 

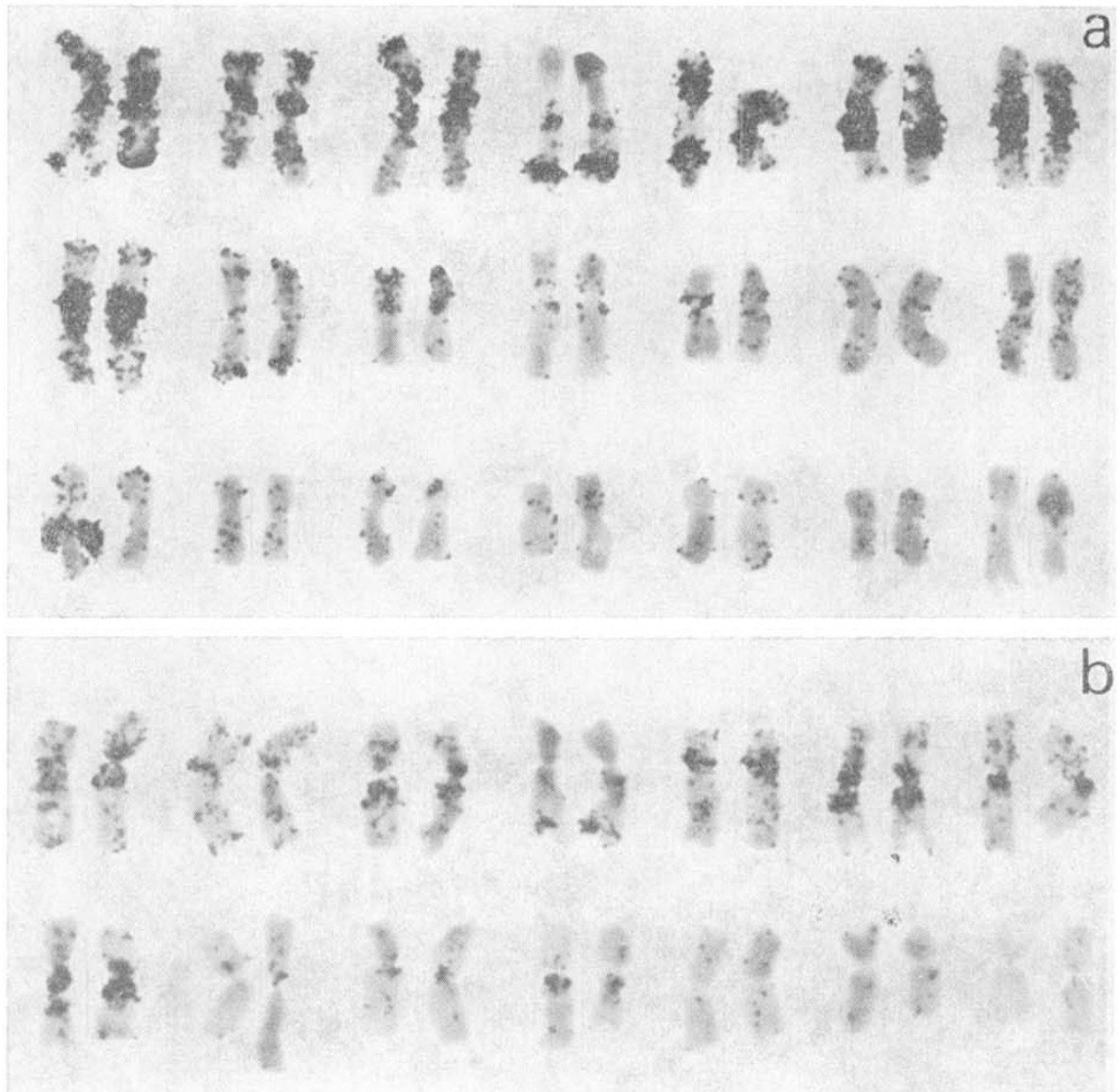

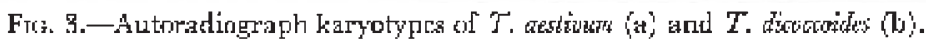

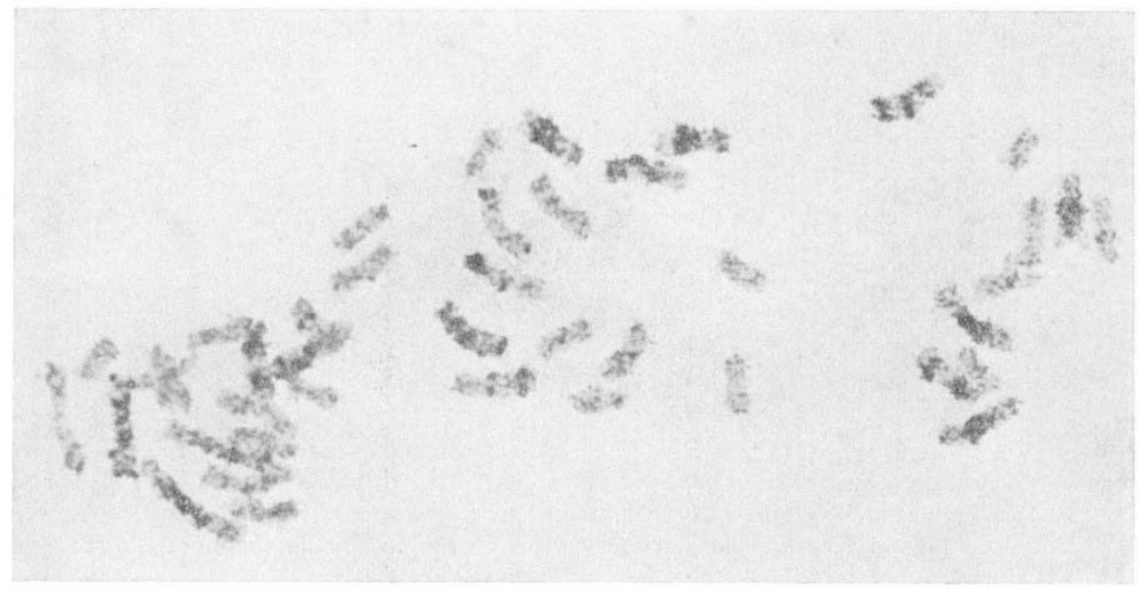

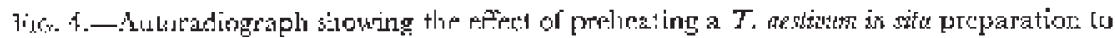

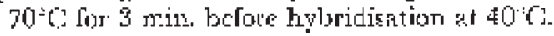


$\mathrm{C}_{0} \mathrm{t} 10^{-2}$ fraction may be the result of additional sequences since the yield from the second isolation was greater. The hyperchromicity of the second $\mathrm{C}_{0} \mathrm{t} 10^{-2}$ isolate was 28.7 per cent compared to $31 \cdot 5$ per cent for native total wheat DNA melted during this experiment. These observations suggest that the $\mathrm{C}_{0} \mathrm{t} 10^{-2}$ samples contain well-matched hybrids which are relatively $\mathrm{GG}$ rich compared with total wheat DNA.

It seems likely that most of the $\mathrm{G}_{0} \mathrm{t} 10^{-2} \mathrm{DNA}$ corresponds to the sequences in the late melting broad portion of the melting profile of total wheat DNA; the $T_{m}$ of the hybrids must be within a few degrees of their native $T_{m}$. This contrasts with other $\mathrm{C}_{0} \mathrm{t} 10^{-2}$ fractions isolated from hexaploid wheat at $60^{\circ} \mathrm{C}$ in $0.12 \mathrm{M} \mathrm{PB}$ which had $T_{m}$ values $=10^{\circ} \mathrm{C}$ lower than native, total wheat DNA (Dover, 1975; Smith and Flavell, 1975; Ranjekar et al., 1976). The differences presumably relate to the high stringency of the present experiments. Also, the hydroxyapatite binding ability of mismatched hybrids is probably lower at $70^{\circ} \mathrm{C}$ than at $60^{\circ} \mathrm{C}$ (Britten et al., 1974).

A feature of the melting profile of the $\mathrm{C}_{0} \mathrm{t} 10^{-2} \mathrm{DNA}$ is a single, latemelting transition which comprises about 50 per cent of the melt profile. If this represents one sequence it would constitute more than 2 per cent of the wheat genome.

\section{(ii) Chromosomal locations}

The $\mathrm{C}_{0} \mathrm{t} 10^{-2} \mathrm{cRNA}$ hybridised to a number of distinctive sites on wheat chromosomes. Autoradiographs of a root tip mitotic metaphase preparation (fig. 2a) and karyotypes (fig. 3a) of Triticum aestivum (genome constitution = AABBDD, $2 n=42$ ) and $T$. dicoccoides (AABB $2 n=28$, fig. $3 \mathrm{~b}$ ) after in situ hybridisation with $\mathrm{C}_{0} \mathrm{t} 10^{-2} \mathrm{cRNA}$ at $40^{\circ} \mathrm{C}$ show that a number of heavily labelled chromosomes are common to both $T$. aestivum and $T$. dicoccoides. In contrast, chromosomes of the diploid species $T$. monococcum (AA, $2 n=14$, fig. $2 \mathrm{~b}$ ) and $A$. squarrosa (DD, $2 n=14$, fig. $2 \mathrm{c}$ ) show only light hybridisation after comparable exposures. From these results it can be concluded that most of the labelled chromosomes are B genome chromosomes.

Fig. 4 shows the effect of " pre-heating "Triticum aestivum in situ hybridisation preparations (i.e., both cRNA probe and chromosomal DNA) to $70^{\circ} \mathrm{C}$ for $3 \mathrm{~min}$. before hybridisation at $40^{\circ} \mathrm{G}$, the exposure time of the autoradiograph being the same as that for the preparation in fig. 2 which was not preheated. The overall extent of labelling is higher and all chromosomes including those from A and D genomes, show substantial label. Sites similar to those seen when hybridisation is performed at $40^{\circ} \mathrm{C}$ without preheating are evident as more heavily labelled areas.

The thermal stability of the hybrids formed at the major sites was compared with those observed at the more general sites. This was done by preparing in situ hybridisation reactions, preheating them to $70^{\circ} \mathrm{C}$ to ensure that all sites were available for hybridisation and then carrying out the hybridisation at $40^{\circ} \mathrm{C}$. After hybridisation duplicate slides were heated to either $45^{\circ} \mathrm{C}, 50^{\circ} \mathrm{C}, 55^{\circ} \mathrm{C}, 60^{\circ} \mathrm{C}$ or $65^{\circ} \mathrm{C}$ in $3 \times \mathrm{SSC}, 50$ per cent formamide for $10 \mathrm{~min}$. before preparing autoradiographs. After both $45^{\circ} \mathrm{C}$ and $50^{\circ} \mathrm{C}$ treatments the slides still showed heavy labelling at major sites and more general labelling as shown in Fig. 4. At $55^{\circ} \mathrm{C}$ the slides showed a substantial decrease in the amount of label at both major and general sites, and at $60^{\circ} \mathrm{C}$ 
and $65^{\circ} \mathrm{C}$ the slides showed no label. Thus, the average thermal stabilities of these hybrids were not markedly different, with average $T_{m}$ 's between $50^{\circ} \mathrm{C}$ and $60^{\circ} \mathrm{C}$.

\section{(iii) Effect of preheating $c R \mathcal{N} A$ and chromosomal $D \mathcal{N} A$ sequences separately}

Preheating of in situ preparations (described above) was originally carried out to determine whether any sequences were present in the cRNA as doublestranded RNA molecules unavailable for hybridisation. Filter hybridisation experiments were used to determine whether preheating does make an increased amount of cRNA available for hybridisation. DNA on nitrocellulose filters was hybridised with cRNA in $3 \times \mathrm{SSC}, 50$ per cent formamide which had been either (1) heated to $70^{\circ} \mathrm{C}$ for $3 \mathrm{~min}$. immediately prior to hybridisation at $40^{\circ} \mathrm{C}$, or (2) maintained at room temperature prior to hybridisation at $40^{\circ} \mathrm{C}$. Filters were removed at intervals and the amount of radioactive cRNA hybridised was determined. Fig. 5 shows that preheating makes additional cRNA sequences available for hybridisation.

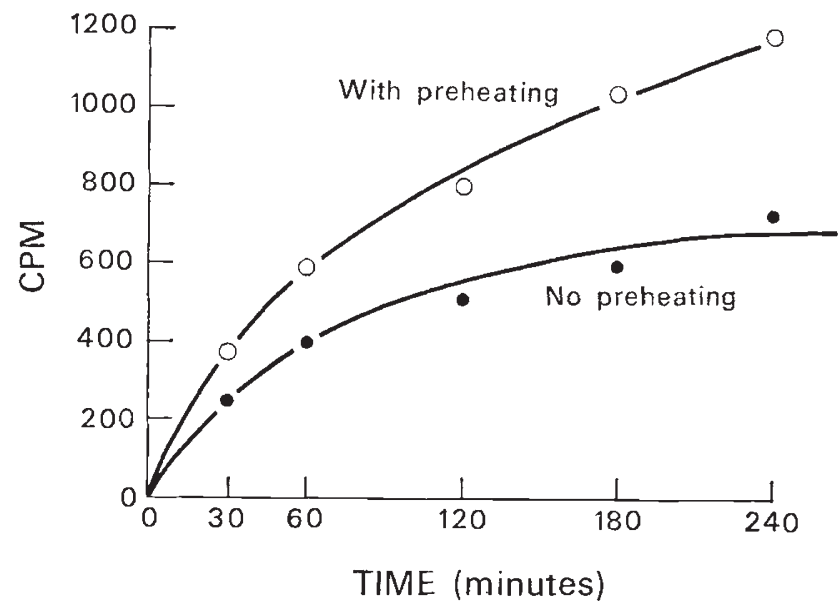

Fig. 5.-Hybridisation of $\mathrm{C}_{0} \mathrm{t} 10^{-2} \mathrm{cRNA}$ to filters containing total wheat DNA with and without preheating of the cRNA to $70^{\circ} \mathrm{C}$ immediately prior to hybridisation. Counts per minute cRNA bound to the filter are plotted against time of incubation of the hybridisation mixture at $40^{\circ} \mathrm{C}$.

The hybrids formed with or without the preheating treatment had melting temperatures within $1^{\circ} \mathrm{C}$ of each other in $3 \times \mathrm{SSC}, 50$ per cent formamide (data not shown), in good agreement with the in situ data.

Since Singh et al. (1977) reported that hybridisation of satellite DNA may be markedly enhanced when heat (or heat + formamide) denaturation is used rather than acid denaturation, the effect of preheating the chromosomal preparations rather than the cRNA was also tested. Chromosome preparations which had been heated in $3 \times \mathrm{SSC}, 50$ per cent formamide $\left(70^{\circ} \mathrm{C}, 3 \mathrm{~min}\right.$.) before loading with hybridisation mixtures at $40^{\circ} \mathrm{C}$ showed labelling patterns similar to that in Fig. 4. Thus, preheating of the chromosomes in $3 \times \mathrm{SSC}$, 50 per cent formamide made available additional, more generally distributed chromosomal sites. 


\section{(iv) The major chromosomal sites contain more than one highly repeated sequence}

A highly repeated DNA sequence which can be isolated as a satellite in $\mathrm{Ag}^{+} / \mathrm{Cs}_{2} \mathrm{SO}_{4}$ buoyant density gradients of total wheat DNA also hybridises to the major chromosomal sites seen in Figs. 2a and 3a (Dennis et al., 1980). An in situ competition hybridisation experiment was carried out to determine whether the hybridisation pattern seen in Fig. 2a, was solely due to hybridisation by the satellite sequence. $\mathrm{C}_{0} \mathrm{t} 10^{-2} \mathrm{cRNA}$ was hybridised to acid denatured chromosomes in the presence of sufficient unlabelled satellite DNA to eliminate hybridisation by the sequences of this satellite in the cRNA (as judged by control experiments). The presence of the unlabelled competitor did not markedly affect hybridisation of the $\mathrm{C}_{0} \mathrm{t} 10^{-2} \mathrm{cRNA}$ indicating that more than one particular highly repeated sequence must be present at all the major chromosomal sites. An arrangement of groups of different highly repeated sequences at particular chromosomal locations has been described in Drosophila (Peacock et al., 1977a, b), primates (Gosden et al., 1977) and rye (Bedbrook et al., 1980). It seems likely that wheat also has distinct chromosomal sites which each contain a set of different highly repeated sequences.

\section{Congluding Remarks}

The observation that the $\mathrm{B}$ genome contains almost all of the major sites for highly repeated DNA sequences in wheat was surprising. The three wheat genomes, A, B and D, are considered to have similar informational contents because " homoeologous" chromosomes from each genome can be assigned on the basis of their ability to compensate for each other in aneuploid strains (Sears, 1966) and their similar distribution of genes for detectable isozymes, (Hart and Langston, 1977), but the present study shows that they contain large differences in the distribution and organisation of highly repeated DNA sequences. Flavell et al. (1979) have recently reached the same conclusions in their filter hybridisation studies of rapidly renaturing cereal DNA.

These large differences do not play an essential role in plant viability or fertility since, in most possible combinations, homoeologues from the $\mathrm{A}, \mathrm{B}$ and D genomes can substitute for each other in nullisomic-tetrasomic stocks (Sears, 1966). However, it is notable that compensation is not always complete in these stocks, reduced vigour and fertility being present in a number of compensating aneuploids. This may well result from slightly different genetic informational contents of the homoeologues or, possibly, the effect of the changed proportion of highly repeated DNA. That the highly repeated DNA blocks are maintained in the B genome of several wheat species (Gerlach et al., 1978) suggests some selective maintenance of these sequences in wheat.

Because in situ hybridisation shows that some rapidly renaturing sequence DNA is present on all wheat chromosomes it is likely that specific highly repeated DNA sequences can be developed as molecular probes for the cytological identification of wheat chromosome regions. Some of these sequences will probably label only the major highly repeated sequence locations which are predominantly in the B genome (cf. Dennis et al., 1979), but because there is a general labelling of all chromosomes when in situ 
preparations are preheated, it should be possible to isolate others characteristic of A and D genome chromosomes as well.

Acknowledgments.-The authors are grateful to Dr R. Appels and Dr E. Dennis for helpful comments on the manuscript and to Dr Appels for experimental advice. W. L. Gerlach was supported by a Rothmans Fellowship and was a Visiting Fellow at the Australian National University.

\section{REFERENCES}

BEDBROOK, J. R., JONES, J., O'DELL, M., THOMPSON, R. D., AND FLAVELL, R. B. 1980. A molecular description of telomeric heterochromatin in Secale species. Cell (in Press).

BRitten, R. J., AND kOHNE, D. E. 1968. Repeated sequences in DNA. Science, 161, 529-540. BRITTEN, R. J., GRAHAM, D. E., AND NEUfELD, B. R. 1974. Analysis of repeating DNA sequences by reassociation. Methods Enzymol., 29E, 363-418.

BURGESS, R. R. 1969. A new method for the large scale purification of Escherichia coli DNAdependent RNA polymerase. F. Biol. Chem., 244, 6160-6167.

DENNIS, E. s., GERLACH, w. L., AND PEACOCK, w. J. 1980. Identical polypyrimidinepolypurine satellite DNAs in wheat and barley. Heredity (in Press).

DOVER, G. A. 1975. The heterogeneity of B chromosome DNA: no evidence for a B-chromosome specific repetitive DNA correlated with B-chromosome effects on meitotic pairing in the Triticinae. Chromosoma, 53, 153-173.

FLAVELL, R. B., O'DELL, M., AND SMITH, D. в. 1979. Repeated sequence DNA comparisons between Triticum and Aegilops species. Heredity, 42, 309-322.

FLAVELL, R. B., AND SMITH, D. B. 1976. Nucleotide sequence organisation in the wheat genome. Heredity, 37, 231-252.

FLAVELL, R. B., RIMPAU, J., AND SMITH, D. B. 1977. Repeated sequence DNA relationships in four cereal genomes. Chromosoma, 63, 205-222.

GERLACH, W. L., APPELS, R., DENNIS, E. S., AND PEACOCK, W. J. 1978. Evolution and analysis of wheat genomes using highly repeated DNA sequences. Proc. 5th Int. Wheat Genet. Symp. 1, 81-91.

GOSDEN, J. R., MiTChell, A. R., SEUANEZ, H. N., AND GOSDEN, C. M. 1977. The distribution of sequences complementary to human satellite DNAs I, II and IV in the chromosomes of Chimpanzee (Pan troglodytes), Gorilla (Gorilla gorilla) and Orang Utan (Pongo pygmaeus). Chromosoma 63, 253-271.

haRt, G. E., AND LANGSTON, P. J. 1977. Chromosomal location and evolution of isozyme structural genes in hexaploid wheat. Heredity, 39, 263-277.

HUGUET, T., JOUANIN, L., AND BAZETOUX, s. 1975. Occurrence of palindromic sequences in wheat DNA. Plant Sci. Lett., 5, 379-385.

MITRA, R., AND BHATIA, C. R. 1973. Repeated and non-repeated polynucleotide sequences in diploid and polyploid wheat species. Heredity, 31, 251-262.

PEACOCK, W. J., APPELS, R., DUNSMUIR, P., LOHE, A. R., AND GERLAGH, W. L. 1977a. Highly repeated DNA sequences: chromosomal location and evolutionary conservation. In International Cell Biology 1976-1977, eds. B. R. Brinkley and K. R. Porter. Rockefeller Univ. Press, 1977, pp. 494-506.

PEACOCK, W. J., LOHE, A. R., GERLACH, W. L., DUNSMUIR, P., DENNIS, E. S., AND APPELS, R. 1977b. Fine structure and evolution of DNA in heterochromatin. Cold Spr. Harb. Symp. Quant. Biol., 42, 1121-1135.

RANJEKAR, P. K., Palotta, D., AND lafontaine, J. G. 1976. Analysis of the genome of plants. II. Characterization of repetitive DNA in barley and wheat. Biochim. Biophys. Acta, 425, 30-40.

SEARS, E. R. 1966. Nullisomic-tetrasomic combinations in hexaploid wheat. In Chromosome Manipulations in Plant Genetics, eds. R. Riley and K. R. Lewis. Heredity (Suppl.), 20, $29-45$.

SINGH, L., PURDOM, I. F., AND JONES, K. W. 1977. Effect of different denaturing agents on the detectability of specific DNA sequences of various base compositions by in situ hybridization. Chromosoma, 60, 377-389.

SMITH, D. B., AND FLAVELL, R. B. 1974. The relatedness and evolution of repeated nucleotide sequences in the genomes of some Gramineae species. Biochem. Genet., 12, 243-256.

SMITH, D. B., AND FLAVELL, R. B. 1975. Characterization of the wheat genome by renaturation kinetics. Chromosoma, 50, 223-242.

studier, r. w. 1965. Sedimentation studies of the size and shape of DNA. F. Molec. Biol., $11,373-390$. 